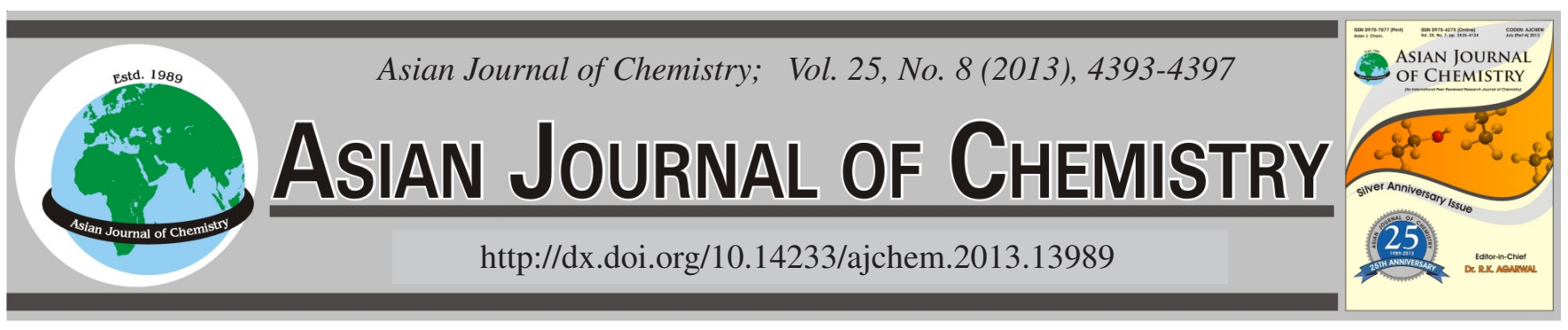

\title{
Stabilization of Heavy Metals in Ceramsite Obtained from Blast Furnace Slag and Sewage Sludge
}

\author{
Z.L. $\mathrm{WANG}^{1,2, *}$ \\ ${ }^{1}$ School of Civil Engineering, Nanjing Forestry University, Nanjing, Jiangsu Province, P.R. China \\ ${ }^{2}$ College of Environment, Hohai University, Nanjing, Jiangsu Province, P.R. China \\ *Corresponding author: Tel: +86 25 85427691; E-mail: wangzhulai@126.com,wangzhulai66@yahoo.com
}

Key Words: Ceramsite, Blast furnace slag, Sewage sludge, Heavy metal, Stabilization.

\section{INTRODUCTION}

With the economic rapid growth of the modern society, the solid wastes become more and more around the world because of people's manufacture and life ${ }^{1,3}$. There are many toxic matters especially heavy metals, which are harmful for people's health existing in these solid wastes, such as blast furnace slag and sewage sludge. In order to decrease the leaching dose of the heavy metals from blast furnace slag and sewage sludge which are not sintered in high temperature, the ceramsite was made from the blast furnace slag and sewage sludge and sintered under high temperature to solidify the heavy metals. The studies on the stabilization of heavy metals in solid wastes especially sewage sludge have been conducted by many researchers, but the studies on that in blast furnace slag alone or the combination of blast furnace slug + sewage sludge $(\mathrm{BFS}+\mathrm{SS})$ are less than sewage sludge alone.

The treatment of municipal wastewater results in the production of huge amounts of sewage sludge and in recent years, the quantity of the total sludge generated all over the world has increased dramatically ${ }^{4}$. The studies on the leaching behaviour and the stabilization of heavy metal from sewage sludge have been carried out by several researchers. Ashish et $a l^{4}{ }^{4}$ studied the various bioleaching behaviour in different modes of operation and the various important aspects such as pathogen destruction, odor reduction and metal recovery from acidic leachate. Montse and Joan ${ }^{5}$ studied the leaching of $\mathrm{Cu}$, $\mathrm{Zn}$ and $\mathrm{Ni}$ from three contrasted Mediterranean forest soils treated with sewage sludges and the relationships between metal mobility and soil properties. $\mathrm{Xu}$ et $a l .{ }^{6,7}$ studied the effects of sintering temperature, $\left(\mathrm{Fe}_{2} \mathrm{O}_{3}+\mathrm{CaO}+\mathrm{MgO}\right) /\left(\mathrm{SiO}_{2}\right.$ $+\mathrm{Al}_{2} \mathrm{O}_{3}$ ) (defined as $\mathrm{F} / \mathrm{SA}$ ratios), $\mathrm{pH}$ and oxidative condition on the stabilization of $\mathrm{Cu}, \mathrm{Cr}, \mathrm{Cd}$ and $\mathrm{Pb}$ in sludge ceramsite. The result showed that the leaching contents of these heavy metals will not change above $1000^{\circ} \mathrm{C}$; the leaching contents of $\mathrm{Cd}, \mathrm{Cu}$ and $\mathrm{Pb}$ increase as the $\mathrm{F} / \mathrm{SA}$ ratios increase; the leaching contents of heavy metals decrease as $\mathrm{pH}$ increases and increase as $\mathrm{H}_{2} \mathrm{O}_{2}$ concentration increases.

Blast furnace slag is a by-product of the manufacture of pig iron from iron ore, limestone and coke. The liquid slag is rapidly cooled by quenching to obtain an almost completely amorphous material. Its chemical composition mainly depends on the composition of the iron ore and potentially contains $27-40 \% \mathrm{SiO}_{2}, 30-50 \% \mathrm{CaO}, 5-15 \% \mathrm{Al}_{2} \mathrm{O}_{3}$ and $1-10 \% \mathrm{MgO}^{8}$. As for the immobilization of heavy metals in slag, the leaching tests are employed to investigate the immobilization behaviours of the slag based geopolymer mortar and the result showed that the slag based geopolymer mortar can effectively immobilize $\mathrm{Cu}$ and $\mathrm{Pb}$ heavy metal ions ${ }^{9}$. 
TABLE-1

ELEMENTS ANALYSES

\begin{tabular}{lccccccccc}
\hline Elements & $\mathrm{Si}$ & $\mathrm{Ca}$ & $\mathrm{Al}$ & $\mathrm{Mg}$ & $\mathrm{Fe}$ & $\mathrm{K}$ & $\mathrm{Na}$ & $\mathrm{P}$ & $\mathrm{Sb}$ \\
\hline BFS (w-\%) & 10.06 & 19.05 & 6.20 & 3.78 & 0.77 & 0.59 & 0.31 & 0.13 & 4.26 \\
SS (w-\%) & 9.24 & 1.39 & 2.97 & 0.53 & 3.68 & 1.48 & 0.22 & 0.33 & 0.42 \\
Clay (w-\%) & 16.68 & 0.69 & 6.28 & 0.78 & 3.19 & 0.99 & 0.63 & 0.05 & - \\
\hline Elements & $\mathrm{Mo}$ & $\mathrm{Sn}$ & $\mathrm{Ti}$ & $\mathrm{Mn}$ & $\mathrm{Cd}$ & $\mathrm{Se}$ & $\mathrm{Pd}$ & $\mathrm{O}$ & $\mathrm{C}$ \\
\hline BFS (w-\%) & 1.94 & 1.94 & 0.56 & 0.16 & 0.02 & - & - & 45.48 & 4.75 \\
SS (w-\%) & 1.09 & 1.64 & 0.32 & 0.07 & - & 0.10 & 0.09 & 30.69 & 45.69 \\
Clay (w-\%) & 0.07 & 1.10 & 0.33 & - & - & - & - & 52.08 & 17.13 \\
\hline
\end{tabular}

From the discussion above, the studies on the development of BFS+SS or blast furnace slag alone ceramsite and its leaching behaviour of heavy metal are less than sewage sludge alone. The objective of this paper is to observe the variation of the leaching behaviour of the heavy metals in the ceramiste manufactured from blast furnace slag and sewage sludge during the different experimental environment such as the preheating and sintering temperature, $\mathrm{pH}$ and $\mathrm{HNO}_{3}$. Meanwhile, the safety of the sintered ceramsite which will be applied for the treatment of water and waste water will be verified by this study.

\section{EXPERIMENTAL}

Blast furnace slag in this paper is obtained from the energy factory of MA STEEL group, MaAnShan, China. Blast furnace slag is a type of granular residue which is produced by water quickly cooling in the process of steel making in blast furnace. Sewage sludge is produced from dewatering workshop of Jiangxinzhou Wastewater Treatment Plant, Nanjing, China. In this plant, wastewater treatment technology is made of primary sedimentation basin, $\mathrm{A} / \mathrm{O}$ and secondary sedimentation basin and the sludge dewatered by pressure filter comes from the excess sludge of secondary sedimentation basin. Clay is obtained from the work site in the 3rd Bridge of Yangtze River, Nanjing, China and the plasticity index of clay is over 17.

The chemical compositions of three raw materials mentioned above are shown in Table- 1 .

The raw materials are ground by SF-130C pulverizer (made in China) at sizes below $100 \mathrm{~mm}$ that are sufficiently fine to be mixed homogeneously. Three sorts ceramiste in the following experiments defined as SSA, SSB and SSC, respectively, are manufactured by the methods as shown in Table-2.

TABLE-2

SAMPLES CONTENTS AND RATIOS

\begin{tabular}{cccccc}
\hline $\begin{array}{c}\text { Type of } \\
\text { ceramsite }\end{array}$ & $\begin{array}{c}\mathrm{Cu} \\
\left(\mathrm{mg} \mathrm{kg}^{-1}\right)\end{array}$ & $\begin{array}{c}\mathrm{Ni} \\
\left(\mathrm{mg} \mathrm{kg}^{-1}\right)\end{array}$ & $\begin{array}{c}\mathrm{BFS} \\
(\mathrm{w}-\%)\end{array}$ & $\begin{array}{c}\mathrm{SS} \\
(\mathrm{w}-\%)\end{array}$ & $\begin{array}{c}\text { Clay } \\
(\mathrm{w}-\%)\end{array}$ \\
\hline SSA & 100 & 100 & 20 & 50 & 30 \\
SSB & 300 & 300 & 20 & 50 & 30 \\
SSC & 500 & 500 & 20 & 50 & 30 \\
\hline
\end{tabular}

$\mathrm{CuSO}_{4} .5 \mathrm{H}_{2} \mathrm{O}$ and $\mathrm{NiSO}_{4} .6 \mathrm{H}_{2} \mathrm{O}$ are dissolved in water solution, which is poured into the mixture of three raw materials. The raw materials are used by DZ-60 pelletizing machine (made in China) to pelletize ceramsite with particle sizes of 4-6 $\mathrm{mm}$ and left in a room at a temperature of about $20^{\circ} \mathrm{C}$ for 4 days and then the samples were dried at $105^{\circ} \mathrm{C}$ in a drying oven for $24 \mathrm{~h}$. The samples are sintered in different temperatures in a muffle furnace (Sx2-12-12, made in China). The variation of $\mathrm{pH}$ is adjusted by $\mathrm{H}_{2} \mathrm{SO}_{4}$ and $\mathrm{NaOH}$. The different concentrations of $\mathrm{HNO}_{3}$ are diluted by concentrated nitric acid. The leaching behaviour is tested by horizontal vibration method (HJ557-2010, Chinese national standard). The chemical compositions of the raw materials are measured by electron energy disperse spectroscopy (INCA 250 EDS, UK). The concentration of heavy metals which leachs from the ceramsite to the water solution is measured by plasma spectrometer(J-A1100, US).

\section{RESULTS AND DISCUSSION}

Effect of preheating temperature on leaching behaviour of heavy metals in ceramite: To evaluate the effect of the preheating temperature on the leaching behaviour of $\mathrm{Cu}$ and $\mathrm{Ni}$, the experiment on SSA, SSB and SSC chose as samples is conducted at the same duration $20 \mathrm{~min}$ and different temperatures: $300,400,500$ and $600{ }^{\circ} \mathrm{C}$. The results are shown in Figs. 1 and 2.

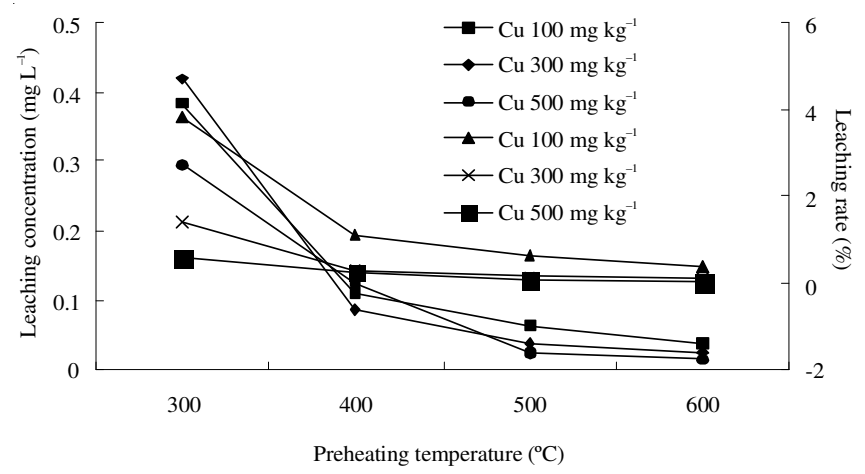

Fig. 1. Effect of preheating temperature on leaching behaviour of $\mathrm{Cu}^{2+}$

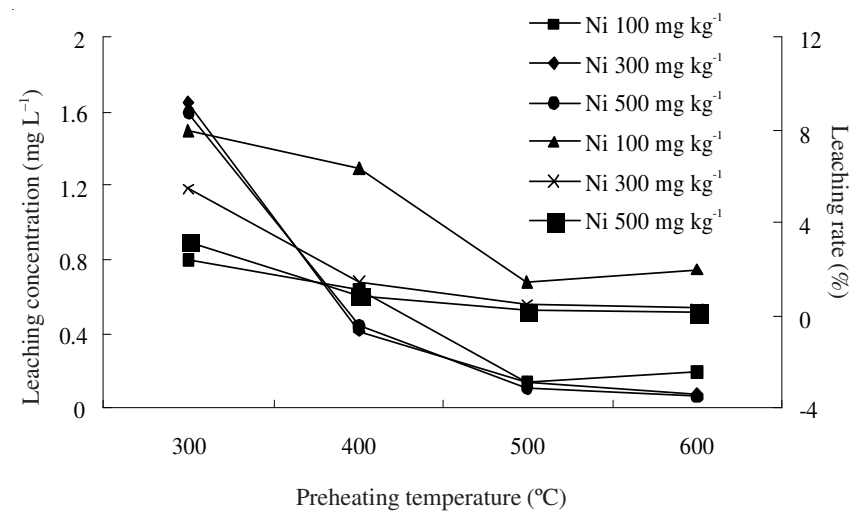

Fig. 2. Effect of preheating temperature on leaching behaviour of $\mathrm{Ni}^{2+}$ 
It can be seen from Figs. 1 and 2 that the leaching concentration and leaching rate of $\mathrm{Cu}$ and $\mathrm{Ni}$ gradually decreases when the preheating temperature varies from 300 to $600{ }^{\circ} \mathrm{C}$. But from 300 to $400{ }^{\circ} \mathrm{C}$ the decrease of the leaching concentration and leaching rate of $\mathrm{Cu}$ and $\mathrm{Ni}$ is more than from 400 to $600{ }^{\circ} \mathrm{C}$. When the preheating temperature is $300{ }^{\circ} \mathrm{C}$, according to the content of $\mathrm{Cu}$ the order of the leaching concentration of $\mathrm{Cu}$ is $500,100,300 \mathrm{mg} \mathrm{kg}^{-1}$ and the most is $300 \mathrm{mg}$ $\mathrm{kg}^{-1}$. When the preheating temperature is $600^{\circ} \mathrm{C}$, the order of the leaching concentration of $\mathrm{Cu}$ is $500,300,100 \mathrm{mg} \mathrm{kg}^{-1}$ and the found maximum for $100 \mathrm{mg} \mathrm{kg}^{-1}$. The order of the leaching rate of $\mathrm{Cu}$ is always $500,300,100 \mathrm{mg} \mathrm{kg}^{-1}$ and the found maximum for $100 \mathrm{mg} \mathrm{kg}^{-1}$ which ever preheating temperature it is. According to the content of $\mathrm{Ni}$ the order of the leaching concentration of $\mathrm{Ni}$ is $100,500,300 \mathrm{mg} \mathrm{kg}^{-1}$ and the found maximum for $300 \mathrm{mg} \mathrm{kg}^{-1}$ when the preheating temperature is $300{ }^{\circ} \mathrm{C}$. The order of the leaching concentration of $\mathrm{Ni}$ was 500,300 , $100 \mathrm{mg} \mathrm{kg}^{-1}$ and the found maximum for $100 \mathrm{mg} \mathrm{kg}^{-1}$ when the preheating temperature is $600^{\circ} \mathrm{C}$. The variation of the order of the leaching rate of $\mathrm{Ni}$ was identical to $\mathrm{Cu}$.

The explanation of the above phenomenon is that with the increase of the preheating temperature, the water molecule especially bound water is volatilized from the ceramiste, which is more solid than before so that the $\mathrm{Cu}$ and $\mathrm{Ni}$ is difficult to leach from the ceramiste and the volatilization is the most from 300 to $400{ }^{\circ} \mathrm{C}$. Meanwhile, the ceramsite is easy to solve in the water solution at the lower preheating temperature owing to its incomplete sintering so that the content of heavy metals increases. As the preheating temperature and the content of $\mathrm{Cu}$ and $\mathrm{Ni}$ increase, the solidification of heavy metals become more effective so that the leaching rates of $\mathrm{Cu}$ and $\mathrm{Ni}$ are the least when the content of $\mathrm{Cu}$ and $\mathrm{Ni}$ is the most $\left(500 \mathrm{mg} \mathrm{kg}^{-1}\right)$.

Effect of sintering temperature on leaching behaviour of heavy metals in ceramite: To examine the effect of the sintering temperature on the leaching behaviour of $\mathrm{Cu}$ and $\mathrm{Ni}$, the experiment on SSA, SSB and SSC chose as samples is carried out at the following condition: preheating temperature $\left(400^{\circ} \mathrm{C}\right)$ and duration $(20 \mathrm{~min})$ and sintering temperature $(900$, 1000,1050 and $1100^{\circ} \mathrm{C}$ ) and duration $(20 \mathrm{~min})$. The result is as following Figs. 3 and 4 .

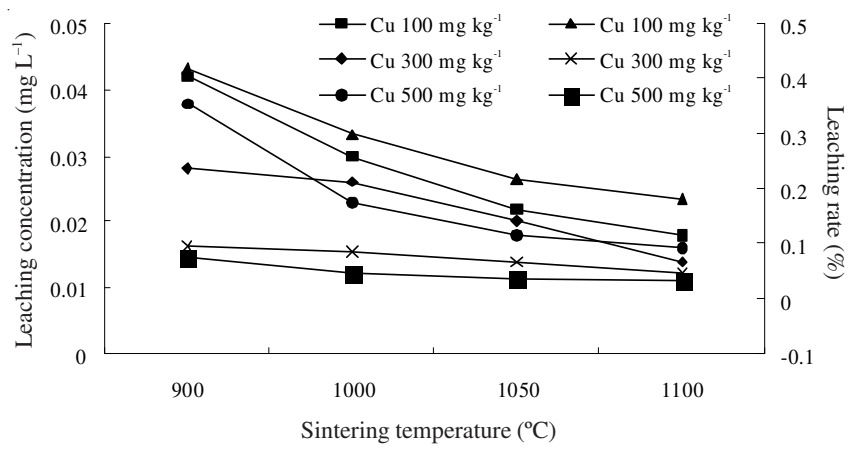

Fig. 3. Effect of sintering temperature on leaching behaviour of $\mathrm{Cu}^{2+}$

It can be seen from Figs. 3 and 4 that with the increase of the sintering temperature, the leaching concentration of $\mathrm{Cu}$ and $\mathrm{Ni}$ gradually decreases. From 900 to $1000^{\circ} \mathrm{C}$ the variation of the curve of $\mathrm{Cu}$ and $\mathrm{Ni}$ is very sharp but from 1050 to 1100 ${ }^{\circ} \mathrm{C}$ the variation become much gentle so that the difference of the leaching concentration of $\mathrm{Cu}$ and $\mathrm{Ni}$ is very less when the sintering temperature is $1100{ }^{\circ} \mathrm{C}$. When the content of $\mathrm{Cu}$ and $\mathrm{Ni}$ is $100 \mathrm{mg} \mathrm{kg}^{-1}$, the variation of the leaching rate is sharp but the variation is less as the content of $\mathrm{Cu}$ and $\mathrm{Ni}$ is $300 \mathrm{mg}$ $\mathrm{kg}^{-1}$ and $500 \mathrm{mg} \mathrm{kg}^{-1}$. Meanwhile, the final order of the leaching rate of $\mathrm{Cu}$ and $\mathrm{Ni}$ is 100,300 and $500 \mathrm{mg} \mathrm{kg}^{-1}$ (the most is 100 $\left.\mathrm{mg} \mathrm{kg}^{-1}\right)$. The reason of above phenomenon is that as the sintering temperature increases, the inner small pores of the ceramsite gradually are melted to become larger pores so that the ceramsite is more dense. In fact, with the increase of the sintering temperature, the complex compounds of $\mathrm{Cu}$ and $\mathrm{Ni}$ are formed and the types of them may be different at different temperature. The crystal of $\mathrm{Cu}$ and $\mathrm{Ni}$ begin forming when the sintering temperature is below $1000{ }^{\circ} \mathrm{C}$ and the crystals of $\mathrm{Cu}$ and $\mathrm{Ni}$ basically have been formed at the sintering temperature of $1000{ }^{\circ} \mathrm{C}$.

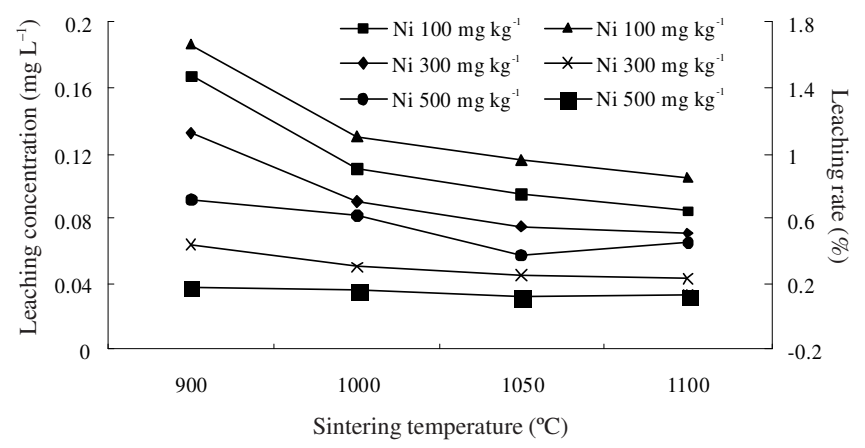

Fig. 4. Effect of sintering temperature on leaching behaviour of $\mathrm{Ni}^{2+}$

Effect of pH on leaching behaviour of heavy metals in ceramsite: To observe the effect of $\mathrm{pH}$ on the leaching behaviour of $\mathrm{Cu}$ and $\mathrm{Ni}$ in the ceramsite, the experiment on SSA, SSB and SSC chose as samples was conducted at the following conditions: preheating temperature $\left(400{ }^{\circ} \mathrm{C}\right)$ and duration $(20 \mathrm{~min})$, sintering temperature $\left(1000^{\circ} \mathrm{C}\right)$ and duration (20 min) and $\mathrm{pH}(1,3,5,7$ and 9). The results are as following Figs. 5 and 6.

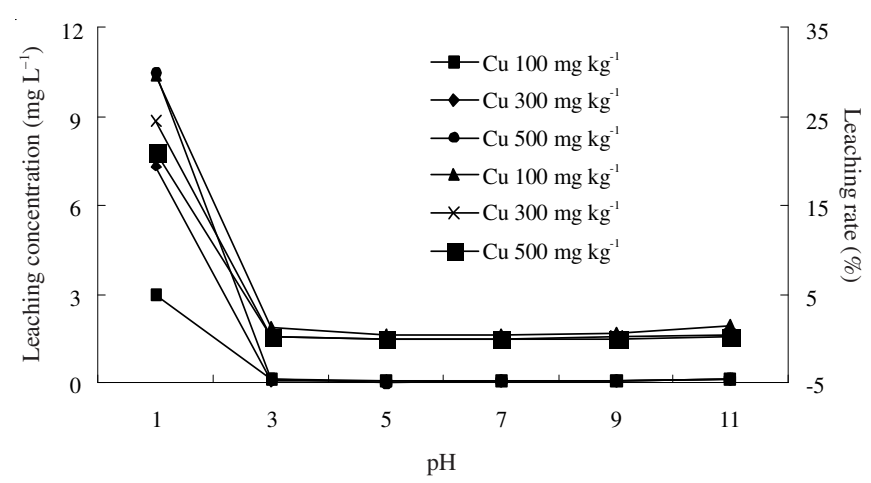

Fig. 5. Effect of $\mathrm{pH}$ on leaching behaviour of $\mathrm{Cu}^{2+}$

It can be seen from Figs. 5 and 6 that when $\mathrm{pH}$ is from 1 to 3 , the leaching concentration of $\mathrm{Cu}$ and $\mathrm{Ni}$ dramatically decreases, but the variation of the leaching concentration is very less remaining below $0.5 \mathrm{mg} \mathrm{L}^{-1}$ as $\mathrm{pH}>3$. When $\mathrm{pH}=1$, the order of the leaching concentration of $\mathrm{Cu}$ and $\mathrm{Ni}$ is 500 , $300,100 \mathrm{mg} \mathrm{kg}^{-1}$ (the content of $\mathrm{Cu}$ and $\mathrm{Ni}$ ) and the maximum was $500 \mathrm{mg} \mathrm{kg}^{-1}$. The difference of the leaching concentration 
among the different content of $\mathrm{Cu}$ and $\mathrm{Ni}$ almost negligible as $\mathrm{pH}>3$. The order of the leaching rate of $\mathrm{Cu}$ and $\mathrm{Ni}$ was the same as $100,300,500 \mathrm{mg} \mathrm{kg}^{-1}$ and the maximum was $100 \mathrm{mg}$ $\mathrm{kg}^{-1}$ when $\mathrm{pH}=1$. The variation of the leaching rate of $\mathrm{Cu}$ and $\mathrm{Ni}$ is identical to the variation of the leaching concentration as $\mathrm{pH}$ is from 1 to 11 . The above phenomenon indicates that the relationship between heavy metals mobility and $\mathrm{pH}$ is complicated and the solubility of heavy metals in the ceramsite is dramatically influenced by lower $\mathrm{pH}$ such as $\mathrm{pH}=1$, also reported in previous studies ${ }^{7}$. The explanation of above phenomenon is that the pores are slowly filled by the solution containing $\mathrm{Cu}$ and $\mathrm{Ni}$ so that the $\mathrm{pH}$ in the pores gradually decreases especially at $\mathrm{pH}=1$ and $\mathrm{Cu}$ and $\mathrm{Ni}$ in this region start to leach from the ceramsite. The initial released metals likely originate from the outer surface of the ceramsite. The residual amounts of $\mathrm{Cu}$ and $\mathrm{Ni}$ in the sintered ceramsite appear to be efficiently immobilized within the silicates or aluminosilicates matrix. This implies that stronger chemical bonds are formed between these heavy metals and the components in ceramsite, making heavy metals difficult to be leached.

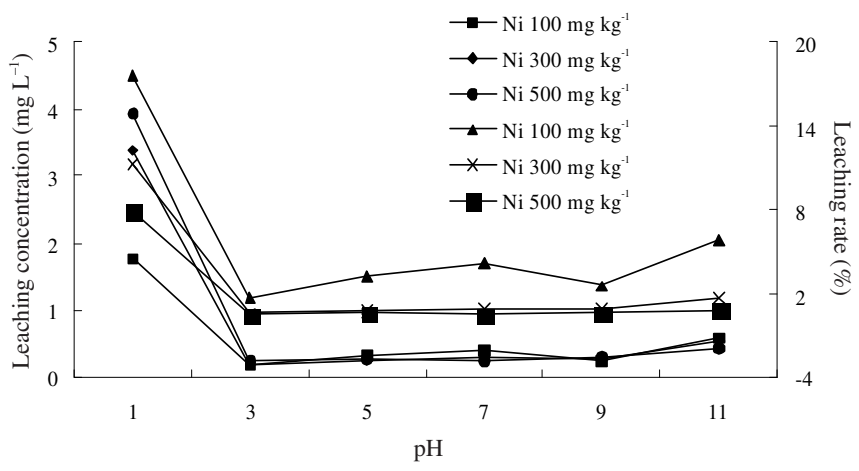

Fig. 6. Effect of $\mathrm{pH}$ on leaching behaviour of $\mathrm{Ni}^{2+}$

Effect of $\mathrm{HNO}_{3}$ concentration on leaching behaviour of heavy metals in ceramite: To examine the effect of oxidative condition on the leaching behaviour of $\mathrm{Cu}$ and $\mathrm{Ni}$ in the ceramsite, the experiment on SSA, SSB and SSC chose as samples is carried out at the following condition: preheating temperature $\left(400{ }^{\circ} \mathrm{C}\right)$ and duration $(20 \mathrm{~min})$, sintering temperature $\left(1000{ }^{\circ} \mathrm{C}\right)$ and duration $(20 \mathrm{~min})$ and $\mathrm{HNO}_{3}(0.5,1.0$, $1.5,2,2.5$ and $\left.3.0 \mathrm{~mol} \mathrm{~L}^{-1}\right)$. The results are shown in Figs. 7 and 8 .

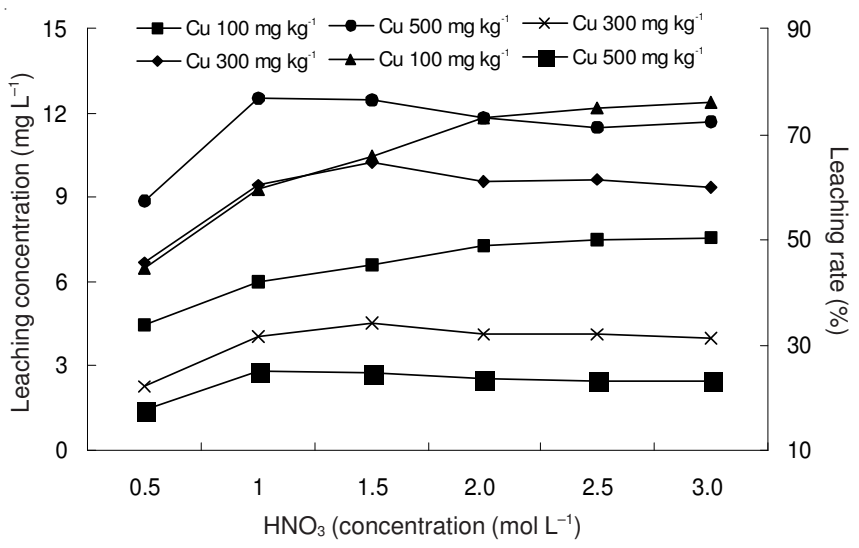

Fig. 7. Effect of $\mathrm{HNO}_{3}$ on leaching behaviour of $\mathrm{Cu}^{2+}$

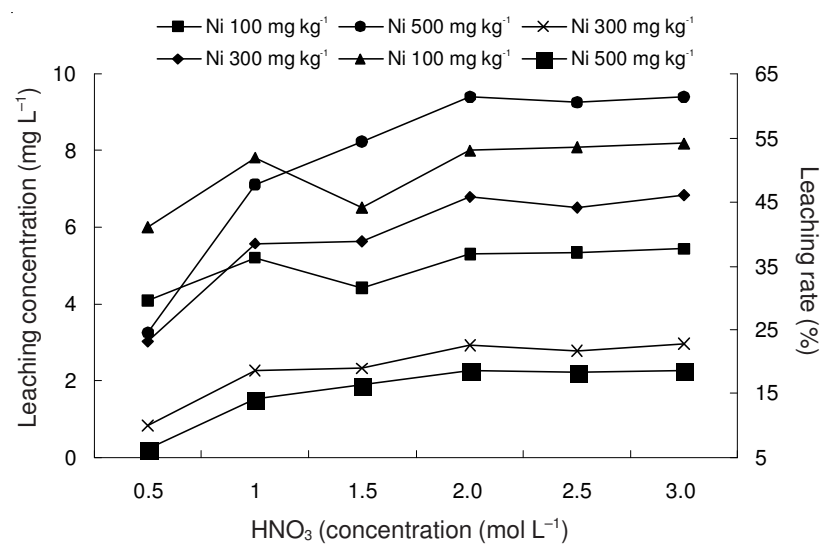

Fig. 8. Effect of $\mathrm{HNO}_{3}$ on leaching behaviour of $\mathrm{Ni}^{2+}$

It can be seen from Figs. 7 and 8 that when the $\mathrm{HNO}_{3}$ concentration increases from 0.5 to $1.0 \mathrm{~mol} \mathrm{~L}^{-1}$, the leaching concentrations of $\mathrm{Cu}$ and $\mathrm{Ni}$ from the ceramsite have a sharp rise. But as the $\mathrm{HNO}_{3}$ concentration is more than $1.0 \mathrm{~mol} \mathrm{~L}^{-1}$, the leaching concentration of them increased slowly especially $\mathrm{Cu}$. When the content of $\mathrm{Cu}$ and $\mathrm{Ni}$ are both $100 \mathrm{mg} \mathrm{kg}^{-1}$, the leaching rate gradually increases with the increase of the $\mathrm{HNO}_{3}$ concentration, in contrast, the variations of the leaching rate of $\mathrm{Cu}$ and $\mathrm{Ni}$ have little difference as the contents of them are 300 and $500 \mathrm{mg} \mathrm{kg}^{-1}$. The result indicates that the influences of the $\mathrm{HNO}_{3}$ concentration on the leaching concentration and rate almost negligible. The reason of above changes is that during the sintering process, the Si may be substituted for the $\mathrm{Al}$ in a network tetrahedron, contributing to the stability of the network. Therefore, $\mathrm{Al}_{2} \mathrm{O}_{3}$ can enter the silica network as $\mathrm{AlO}_{4}{ }^{4-}$ tetrahedra to replace some of $\mathrm{SiO}_{4}{ }^{4-}$ groups ${ }^{10}$. These complex chemical reactions need the incorporation of many cations including $\mathrm{Cu}$ and $\mathrm{Ni}$ into the structure ${ }^{11}$. Therefore, even put in the high $\mathrm{HNO}_{3}$ concentration, the ceramsite structures still have good binding ability and heavy metals cannot be easily leached from the ceramsite to the leachant.

\section{Conclusion}

Based on the above discussion, the following conclusions may be drawn as follows:

(1) With the increase of the preheating temperature, the leaching concentration and leaching rate of $\mathrm{Cu}$ and $\mathrm{Ni}$ have a significant decrease especially the temperature from 300 to $400{ }^{\circ} \mathrm{C}$. The influence of the preheating temperature on the leaching concentration and leaching rate is very obvious.

(2) The leaching concentration of $\mathrm{Cu}$ and $\mathrm{Ni}$ gradually decreases as the sintering temperature increases and the sintering temperature has a important influence on the leaching concentration. The leaching rate of $\mathrm{Cu}$ and $\mathrm{Ni}$ gradually declines with the increase of the sintering temperature when the contents of $\mathrm{Cu}$ and $\mathrm{Ni}$ are $100 \mathrm{mg} \mathrm{kg}^{-1}$, in contrast, as the contents of $\mathrm{Cu}$ and $\mathrm{Ni}$ are 300 and $500 \mathrm{mg} \mathrm{kg}^{-1}$, respectively the variations of the leaching rate are very less.

(3) As $\mathrm{pH}=1$, both the leaching concentration and leaching rate of $\mathrm{Cu}$ and $\mathrm{Ni}$ are the maximum. When $\mathrm{pH}$ varies from 3 to 7, the changes of the leaching concentration and leaching rate are not obvious. Except $\mathrm{pH}=1$, the influence of the variation of $\mathrm{pH}$ on the leaching concentration and leaching rate of $\mathrm{Cu}$ and $\mathrm{Ni}$ is very less. 
(4) When the $\mathrm{HNO}_{3}$ concentration increases from 0.5 to $1.0 \mathrm{~mol} \mathrm{~L}^{-1}$, the leaching concentration and leaching rate of $\mathrm{Cu}$ and $\mathrm{Ni}$ have a sharp rise, in contrast, the variation of them is not significant as the $\mathrm{HNO}_{3}$ concentration $>1.0 \mathrm{~mol} \mathrm{~L}-1$. In general, the oxidative condition of $\mathrm{HNO}_{3}$ has not a obvious influence on the leaching concentration and leaching rate except the $\mathrm{HNO}_{3}$ concentration $=0.5 \mathrm{~mol} \mathrm{~L}^{-1}$.

\section{ACKNOWLEDGEMENTS}

The author gratefully acknowledged the financial support by the Priority Academic Program Development of Jiangsu Higher Education Institutions, China.

\section{REFERENCES}

1. H.B. Duan, Q.F. Huang, Q. Wang, B.Y. Zhou and J.H. Li, J. Hazard. Mater, 158, 221 (2008).

2. P.T. Nguyen, M. Yasuhiro and F. Takeshi, J. Environ. Manage., 91, 2307 (2010).

3. M. Alexandre, D. Filipe and S. Viriato, Waste Manage., 26, 1477 (2006).

4. P. Ashish, M.G. Dastidar and T.R. Sreekrishnan, J. Environ. Manage., 90, 2343 (2009).

5. T. Montse and R. Joan, Sci. Total Environ., 363, 11 (2006).

6. G.R. Xu, J.L. Zou and G.B. Li, J. Hazard. Mater., 153, 1031 (2008).

7. G.R. Xu, J.L. Zou and G.B. Li, Water Res., 44, 2930 (2010).

8. F. Bellmann and J. Stark, Cement Concrete Res., 39, 644 (2009).

9. Y.S. Zhang, W. Sun, Q.L. Chen and L. Chen, J. Hazard. Mater, 143, 206 (2007).

10. Y.S. Liu and Y.S. Liu, Environ. Sci. Technol., 39, 3855 (2005).

11. M.D. Ho and G.J. Evans, Environ. Sci. Technol., 34, 1030 (2000). 